\title{
未分化癌と思われた巨大良性甲状腺腫例
}

\author{
東野 正明 - 河田 了・山口 智子・吉村 勝弘 \\ 野中隆三郎・萩森 伸一・竹中 洋・过求*

\section{Large Benign Thyroid Tumor Suspected of Anaplastic Thyroid Carcinoma}

\author{
Masaaki Higashino, Ryo Kawata, Tomoko Yamaguchi, \\ Katsuhiro Yoshimura, Ryuzaburo Nonaka, Shinichi Haginomori, \\ Hiroshi Takenaka and Motomu Tsuji \\ (Osaka Medical College)
}

\begin{abstract}
We reported large thyroid tumor in a 75-year old female who presented with cervical tumor. The patient first noticed the mass 30 years previously, however the mass had not enlarged. Then the tumor rapidly enlarged within one week with pain. On the initial examination in our hospital, the tumor was over $10 \mathrm{~cm}$, reaching the submandibular gland. The tumor was diagnosed as thyroid malignant tumor by fine needle aspiration biopsy (FNA). The histological diagnosis suggested findings anaplastic carcinoma based on the present history, FNA findings and inflammatory response of blood examination. However, the tumor did not grow after administration and there was no accumulation on Ga scintigram. So we performed hemithyroidectomy alone after one week of administration, and the tumor was diagnosed as follicular adenoma with hematoma by intraoperative frozen section. We suggested that rapid enlargement of the tumor and inflammatory response was due to intratumoral hemorrhage, and misdiagnosis of FNA was due to a complication of chronic thyroiditis.
\end{abstract}

Key words : large thyroid tumor, anaplastic thyroid carcinoma, chronic thyroiditis

はじめに

甲状腺癌の大部分を占める乳頭癌, 濾胞癌は比較的発 育が緩慢で,一般的に予後良好な癌腫とされている. そ れに対して甲状腺未分化癌は甲状腺癌のなかでは約 $2 \%$ にすぎないが，急速に進行し予後がきわめて不良で，1 年以上生存する例はまれとされている ${ }^{1)}$. 診断確定に時 間がかかると, 急速に進行するため初診時に手術可能と 考えられていた症例でも手術不能になる場合もある.今 回，われわれは臨床経過が甲状腺未分化癌を思わせた巨 大甲状腺腫の 1 例を経験したので, 若干の文献的考察を 交えて報告する。

\section{症例}

症例 : 75 歳, 女性.

既往歴, 家族歴 : 特記すべきことなし。

主訴：前頸部腫脹.

現病歴 : 30 年ほど前より前頸部腫脹を自覚し, 他院を 受診していたが, 悪性ではないとのことで経過観察され ていた。平成 13 年 3 月 10 日頃より前頸部腫脹が急に増 大し, 疼痛を伴うようになったため, 近医内科を受診し 3 月 19 日当科へ紹介受診となった.

初診時所見：前頸部から両側頸部にかけて大きな腫瘤 を触知し, 甲状腺が大きく腫大しているものと思われた. 


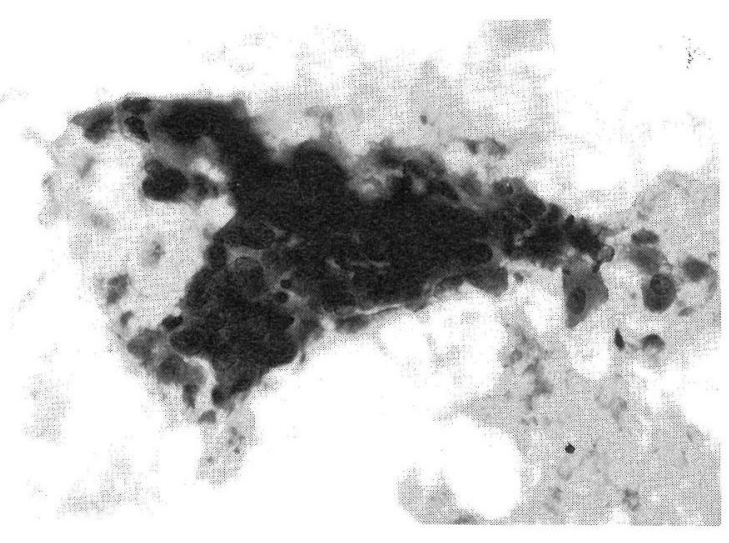

図 1 穿刺吸引細胞診

出血性背景のなかに大型の核クロマチンの粗な甲状腺濾 胞上皮を認めた。また小型の正常なリンパ球が少量散在 性に出現していた。

特に右側頸部では腫瘤は顎下腺と接していた。腫瘤の表 面は平滑で弾性軟，嚥下時の可動性は良好であったが， かなり強い自発痛と圧痛を認めた。声帯運動は良好で反 回神経麻痺は認めなかったが, 軽度の呼吸困難感を訴え ていた。

検查所見: 白血球は $7610 / \mu 1$ と上昇は認めなかったが, CRP $6.1 \mathrm{mg} / \mathrm{dl}$ と上昇していた. 甲状腺機能は正常 であったが，サイログロブリン抗体，マイクロゾーム 抗体はともに陽性であった。サイログロブリン值は $3913.0 \mathrm{ng} / \mathrm{ml}$ と著明に高値であった。

穿刺吸引細胞診（FNA）（図 1）：出現細胞は少なかっ たが，出血性背景のなかに大型の核クロマチンの粗な甲
状腺滤胞上皮を認めた。なお，小型の正常のリンパ球が 少量散在性に出現していた。

造影 CT 所見（図 2）：甲状腺は全体に腫大し，内部は 不均一で囊胞を多数認め, 一部で囊胞壁に石灰化がみら れた。リンパ節の腫大は認めなかった。また，気管が圧 排され内腔は狭窄していたが腫瘍の気管内への浸潤は認 めなかった。

頸部エコ一所見：甲状腺はびまん性に腫大し，内部エ コーは不均一で腫瘤様の部分と明らかな霊胞の部分を認 め, CT 所見と同様であった。

入院経過 : 経過および検查の結果加ら悪性度の強い甲 状腺腫瘍を考元, 初診日から 2 日後の 3 月 21 日入院之 なった，急激に增大した大きな甲状腺腫であること，自 発痛や圧痛を認めたこと, 高齢の女性であること, 詳細 は不明であるが以前甲状腺腫があると診断されていたこ と，血液検查で炎症所見を認めたこと，FNA にて悪性を 疑う細胞を認めたことにより甲状腺乳頭癌の未分化転化 を疑った。しかし，入院まで急激に增大していた腫愓が 入院後はその増大傾向が認められなくなり, 呼吸困難感 む増悪しなかった。また，声帯運動は良好で反回神経麻 痺はなく，未分化癌でない可能性むあると考光た。定期 手術枠外での緊急手術は行わないこととし， 3 月 28 日 ${ }^{67} \mathrm{Ga}$ シンチを施行したところ前頸部に集積を認めず，未 分化癌や悪性リンパ腫は否定的であった。 3 月 28 日，再 度 CT（初回の CT から 9 日後）を施行したところ, 腫瘍 の増大傾向がなかったため, 未分化癌の可能性はさらに 否定された。しかし，たと喜性でないとしても巨大な 腫瘍であるため, 手術適応と考え，定期手術枠で手術を

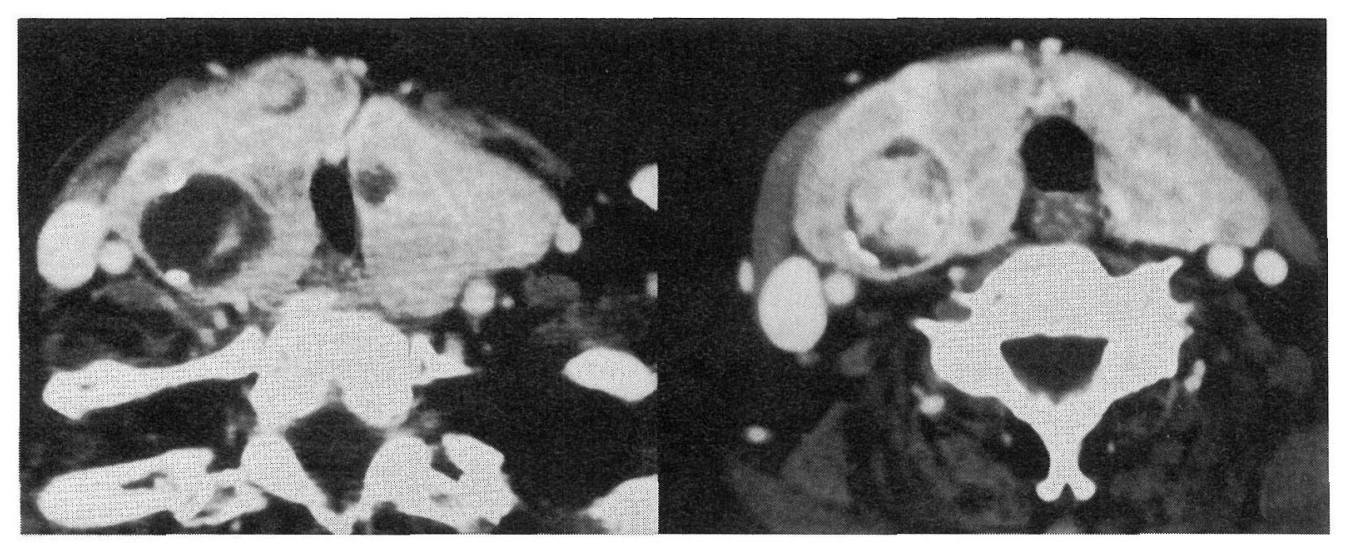

図 2 造影 CT 所見

甲状腺は全体に腫大し, 内部は不均一で囊胞を多数認め, 一部で囊胞壁に石灰化がみられた。 


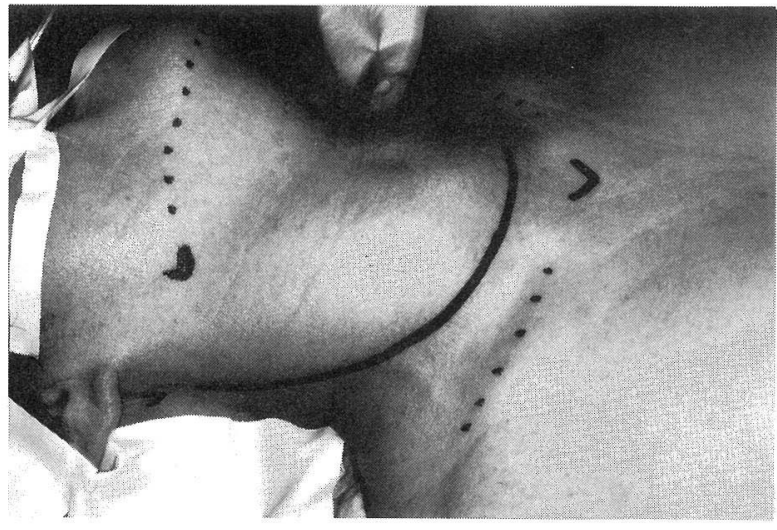

図 3 皮切

腫瘍が大きいため皮膚切開は J 型とした。腫瘍上端は顎下 腺下方に達していた。

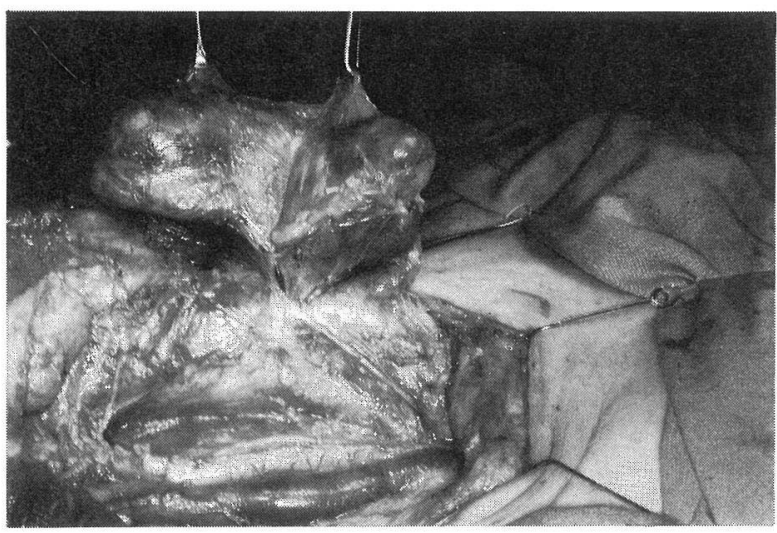

図 4 術中所見

腫瘍と周囲組織の剥離は比較的容易で, 反回神経の発見, 剥離む困難ではなかった。

施行することとした。術式は術中迅速病理診断の結果で 最終決定することにした。

手術所見：4月 2 日, 全身麻酔下に腫瘍摘出術を施行 した。腫瘍が大きいため皮切は J 型とした（図 3)。腫瘍 は画像診断の通り右頸部では上方は顎下腺下方まで存在 し，総頸動脈，内頸静脈は外方に圧排されていた。しか し，腫瘍と周囲組織の剥離は比較的容易で，反回神経の 発見, 剥離も困難ではなかった（図 4). 甲状腺峡部で切 離し，右甲状腺半切術としてその組織を術中病理診断に 提出した。その結果，腫瘍に悪性所見がなく，腫崵の一 部に出血巣がみられた。急激な増大，炎症反応注腫瘍内 出血のためと考えられた（図 5)。術中迅速病理診断で悪

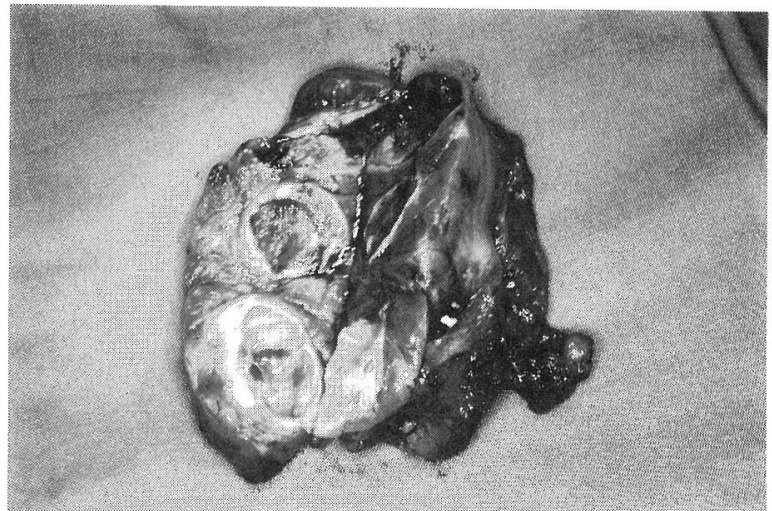

図 5 摘出標本

腫瘍内に囊胞を認め, そのなかには凝血塊が認められた。

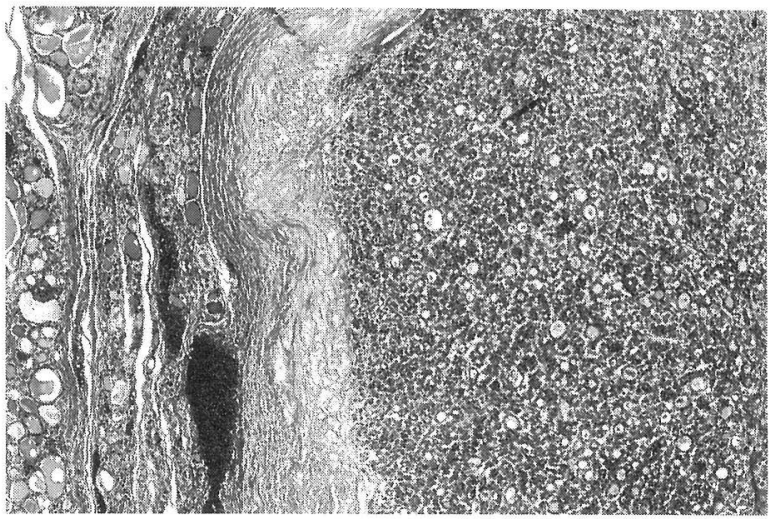

図 6 病理組織学的所見 (HE 染色, $3.3 \times 4$ 倍)

大小の結節性病変は一部石灰沈着を伴った厚い線維性被 膜に囲まれて，内部は小型の甲状腺濾胞上皮を含み，滤 胞腺腫と診断された。

性所見がなかったこと，左葉内にははっきりとした結節 性病変がないことから，甲状腺右葉切除術にとどめた。 頸部リンパ節郭清術は行わなかった。

病理組織像（図 6)：大小の結節性病変は一部石灰沈着 を伴った厚い線維性被膜に囲まれて，内部は小型の甲状 腺滤胞上皮を含み，滤胞腺腫と診断された。なお大きい 方の腫瘍は大半が血液成分で占められていた．腫瘍以外 の部分は大小の甲状腺濾胞よりなり, 間質には散在性に 胚中心を伴ったリンパ滤胞がみられた。その周辺の滤胞 上皮には核の腫大や細胞質の好酸性変化を認めたが，悪 性所見は認めなかった。 


\section{考 察}

甲状腺未分化癌は滤胞上皮由来の悪性腫瘍であり，わ が国での集計では甲状腺癌全体の $1.9 \%$ とされいる23). 最近のアメリカでの報告でも $1.7 \%$ であり，頻度に日米 間の大差はない4)。発生頻度は低いものの，比較的予後 良好の甲状腺分化癌に対し，予後はきわめて不良で 1 年 以上の生存はまれとされている。

甲状腺未分化癌の疫学的特徴は, 分化癌のピークが 40 歳代であるのに対して，60～70 歳代の高齢者に多いこ とである. 男女比は分化癌が約 $1: 6$ であるのに対して, 未分化癌は $1: 2.3$ と報告されている ${ }^{3)}$. 臨床的特徴とし ては，急速に増大する甲状腺腫であり，長期にわたり甲 状腺腫（分化癌）の既往を有するむのが多(5) 7). 分化 癌と異なり, 周囲への浸潤, 圧迫傾向が著明で, 嗄声, 呼吸困難，器下困難などを伴いやすい，一般検查所見で は白血球増多や $\mathrm{CRP}$ 上昇などの炎症反応を認め, 自発痛 や圧痛を伴らことが多(18)。本症例では，1）急速に増大 した巨大な甲状腺腫瘍であったこと，2）高齢の女性で あったこと，3）甲状腺腫の既往があったこと，4）血液 検査で CRP の上昇, 疼痛を認めたこと，5）FNA で異型 細胞を認めたことより, 当初は甲状腺未分化癌と疑った。 しかし，腫瘍が大きい割には反回神経麻痺を伴わないこ と, 触診上腫瘍表面が平滑で, 可動性も比較的良好であ ることから未分化癌の診断に若干の疑問をもった。 そこ で数日間経過を観察したところ，それまで急激に増大し ていた腫瘍は，増大傾向を示さず，疼痛も一時より軽快 してきた. そのため初診時予約しておいた ${ }^{67} \mathrm{Ga}$ シンチの 結果を待つこととした，その結果，腫瘍に一致した集積 は認められず，一般に高度に集積するとされている未分 化癌と異なる結果であった。 再度撮影した CT の所見で も腫崵の増大は認められず，さらに未分化癌は否定的と なった. 結果的に，未分化癌と誤診された原因は，橋本 病が併存していたにもかかわらず, FNA でリンパ球の出 現が少なく，異型上皮細胞がみられたことで悪性を疑っ たためであった。 また未分化癌を疑わせた急激な甲状腺 の増大や血液検査の炎症所見は, 腫瘍内からの出血が原 因と推定された。

甲状腺末分化癌の治療方針として，手術治療，放射線 治療，化学療法があるが，決定的な治療法がなく，症例 数が少ないこともあって，治療方針の詳細に及ぶ統一は 未だなされていないのが現状である．未分化癌が手術治 療単独で根治できるものは, ごく限られた症例である.
しかし, 手術治療は重要な位置を占めていることは疑い ない.たとえ姑息術に終わったとしても, 気道確保といっ た局所制御としての意義がある場合もある ${ }^{9)}$ ．また腫瘍 を減量することが，他の治療法の効果を高める可能性が ある ${ }^{10)}$. 未分化癌 91 症例を検討した Junor ら ${ }^{11)}$ の報告に よれば，腫瘍摘出術を行った群は単に生検にとどめた群 と比較して生存期間が有意に高かった. Nel ら ${ }^{12)}$ も 82 症 例について検討し，根治手術を施行し得た症例は有意に 予後が良いと報告している。 しかし，根治手術が可能な 症例は腫瘍の進展が激しくないとも解釈され, それが甲 状腺未分化癌の治療において手術治療が絶対的な第 1 選 択でない理由であると考えられる。一概に未分化癌と いっても生物学的悪性度にはばらつきがあると思われ， ぞれだけ積極的に加療を行うかを判断する上でも, 治療 前の悪性度評価が重要といえる。杉谷ら ${ }^{13)}$ は未分化癌の 覀性度について評価を行い，1）年齢 75 歳以上，2）男 性，3）1力月以内に急性増悪症状あり，4）腫瘍径 $7 \mathrm{~cm}$ 以上，5）白血球 $10000 / \mathrm{mm}^{3}$ 以上，6）腺外浸潤あり，7） 遠隔転移ありの 7 項目を挙げ，4 項目以上該当する症例 では，6カ月生存がなく，5 項目以上該当する症例では, 3力月生存がなかったとしている.きわめて予後不良の本 疾患を考えたとき，このような予後因子を十分に考慮に 入れて，患者の $\mathrm{QOL}$ を損なわない治療が重要であると 考えられる.

\section{まとめ}

臨床経過より未分化癌を疑った巨大甲状腺腫症例を報 告した. 臨床経過，検查結果から未分化癌を疑ったが, 結果的には囊胞内に出血を伴った濾胞腺腫であった．急 激な腫瘍の増大および炎症反応は囊胞内出血のため, FNAでの悪性細胞出現は橋本病がベースに存在したこと によるものと考えられた。

\section{参考文献}

1) 甲状腺悪性腫瘍登録委員会: 甲状腺悪性腫瘍登録集計 (1977 ～1996). 第31 回甲状腺外科研究会抄録集: $135 \sim 148,1998$.

2）甲状腺外科検討会：甲状腺癌取扱い規約 (第 5 版). 金原出 版, 東京, 1996.

3）甲状腺外科検討会. 甲状腺悪性腫瘍登録委員会：甲状腺悪 性腫瘍登録集計（1977～1995）. 第 30 回甲状腺外科検討会 抄録集，1997.

4) Hundahl SA, Fleming ID, Fremgen AM, et al. : A National Cancer Data Base report on 53, 856 cases of thyroid carcinoma 
treated in the U.S., $1985 \sim 1995$. Cancer $83: 2638 \sim 2648$, 1998.

5) Schlumberger M and Caillou B : Warner and Ingbar's the thyroid, $7^{\text {th }}$ edition. pp 961, Lipincott-Raven Publishers, Philadelphia, 1996.

6) Burman KD, Ringel MD and Wartofsky L : Unusual types of thyroid neoplasms. Endocrinol Metab Clin North Am 25:49 68, 1996.

7) Ain KB : Anaplastic thyroid carcinoma; behavior, biology, and therapeutic approaches. Thyroid 8:715 726, 1998.

8) Chang T, Liaw KY, Kuo SH, et al. : Anaplastic thyroid carcinoma; review of 24 cases, with emphasis on cytodiagnosis and leukocytosis. J Formos Med Assoc $58: 551 \sim 556,1989$.

9）芝 英一, 小林哲郎, 高井新一郎 : 甲状腺未分化癌に対す る集学的治療. 外科治療 $69: 356 \sim 361,1993$.
10）山下共行, 山崎喜代美, 飯原雅季, 他：甲状腺未分化癌の 治療. 外科 $58: 675 \sim 679,1996$.

11) Junor EJ, Paul J and Reed NS : Anaplastic thyroid carcinoma; 91 patients treated by surgery and radiotherapy. Eur J Surg Oncol $18: 83 \sim 88,1992$.

12) Nel C, van Heerden JA, Goellner JR, et al. : Anaplastic carcinoma of the thyroid; a clinicopathologic study of 82 cases. Mayo Clin Proc $60: 51 \sim 58,1985$.

13）杉谷 镢, 藤本吉秀, 河西信勝, 他: 甲状腺未分化癌. JOHNS $15: 923 \sim 926,1999$.

原稿受付：平成14年 1月18日

原稿採択：平成14年 3 月 13 日

別刷請求先 : 東野正明

厂569-8686 高柣市大学町2-7

大阪医科大学耳鼻咽喉科学教室 